\title{
Metode Metode Kontrol Pada Mobil Listrik
}

\author{
Sepdian \\ Politeknik Jambi \\ JL. Lingkar Barat 2. Irg Veteran RT 4 Kel. Bagan Pete Kec. Alam Barajo Kota Jambi \\ sepdian@politeknikjambi.ac.id
}

\begin{abstract}
Abstrac, This paper will cover about how the creation of electric cars and methods methods that are necessary for the achievement of an electric car. The concept of electric cars is not new. As battery technology grew in the late 19th century, several electric vehicles had begun. The development of the automotive world, causing an increase in the need for fuel oil used as fuel for motor vehicles. With rising petroleum prices increasing, the development of electric cars has a great opportunity to solve the problem. The use of electric cars is considered effective in addition to not cause air pollution and the construction of a more simple engine. The use of electric cars would require an electric engine. This dipaper used several control methods to make an electric car, such as motor rotation speed control method, EV / HEV Bidirectional control method, and full cell control method or control method for battery charging.
\end{abstract}

Keywords: electric car, dc motor, full cel, EV / HEV Bidirectional

\begin{abstract}
Abstrak, Paper ini akan mengetengahkan tentang bagaimana terciptanya mobil listrik serta metode metode yg diperlukan untuk tercapainya sebuah mobil listrik. Konsep mobil listrik bukanlah barang baru. Seiring bertambah majunya teknologi baterai pada akhir abad ke 19, beberapa kendaraan listrik sudah mulai dibuat. Perkembangan dunia otomotif, menyebabkan peningkatan kebutuhan akan bahan bakar minyak yang dipakai sebagai bahan bakar kendaraan bermotor. Dengan kenaikan harga minyak bumi yang terus meningkat, maka pengembangan mobil listrik berpeluang besar menjadi penyelesaian masalah tersebut. Penggunaan mobil listrik dirasa efektif selain tidak menimbulkan polusi udara dan konstruksi mesinnya yang lebih sederhana. Penggunaan mobil listrik tentunya membutuhkan mesin listrik. Dipaper ini digunakan beberapa metode kontrol untuk membuat sebuah mobil listrik, seperti metode kontrol kecepatan putaran motor, metode kontrol EV/HEV Bidirectional, dan metode kontrol full cell atau metode kontrol untuk pengisian baterai.
\end{abstract}

Kata kunci : Mobil listrik, motor dc, full cel, EV/HEV Bidirectional.

\section{Pendahuluan}

Perkembangan dunia otomotif, menyebabkan peningkatan kebutuhan akan bahan bakar minyak yang dipakai sebagai bahan bakar kendaraan bermotor. Dengan kenaikan harga minyak bumi yang terus meningkat (meskipun tren harga minyak akhirakhir ini sedang turun), maka tidak ada salahnya kalau industri otomotif mulai mengembangkan mobil hybrid, dan mobil listrik. sehingga struktur pembangkit listrik konvensional memerlukan penetrasi tingkat tinggi sumber energi terbarukan. Energi Matahari adalah sumber energi terbarukan yang paling banyak digunakan. Integrasi dari sistem fotovoltaik ke dalam grid telah menjadi isu utama yang harus ditangani karena tidak tersedianya dan ketidakpastian dari sumber yang berasal dari ketidak seimbangan distribusi energi. Sistem penyimpanan energi adalah salah satu solusi untuk masalah ketidakseimbangan distribusi sistem tenaga listrik (3). dengan metode kontrol bidirectional DC/DC pada EV/HEV (2). Untuk memenuhi perubahan permintaan puncak terutama selama percepatan dan pengereman. Jadi, hibridisasi PEMFC dan sistem penyimpanan energi (ESS) menurunkan Biaya FC dan meningkatkan kinerja dan penyalaan. Baterai (B) tampaknya menjadi kandidat yang paling kuat untuk berhibridisasi dengan PEMFC untuk aplikasi mobil listrik (6).

2. Metode Metode Yang Digunakan

2.1 Metode control pada kecepatan putaran rotor

sebuah interior magnet permanen (IPM) Mesin sinkron dapat mencapai operasi daya dan kecepatan rotor dan motor yang konstan. Sementara desain mesin PHT untuk kecepatan yang lama, Operasinya menimbulkan beberapa tantangan teknis, keberhasilan sistem penggerak lengkap tergantung pada tersedianya algoritma kontrol yang tepat dan dapat mengekstrak penuh kemampuan kinerja dari mesin. Secara khusus, teknik kontrol melemahnya fluks khusus yang diperlukan untuk mencapai operasi daya konstan pada rentang kecepatan yang 
luas. Selama rengtang kecepataan IPM diatur sebagai motor, algoritma kontrol baru yang dirancang untuk mengekstrak hampir konstan listrik dari mesin IPM pada rentang kecepatan lebar ketika itu beroperasi sebagai alternator [1].

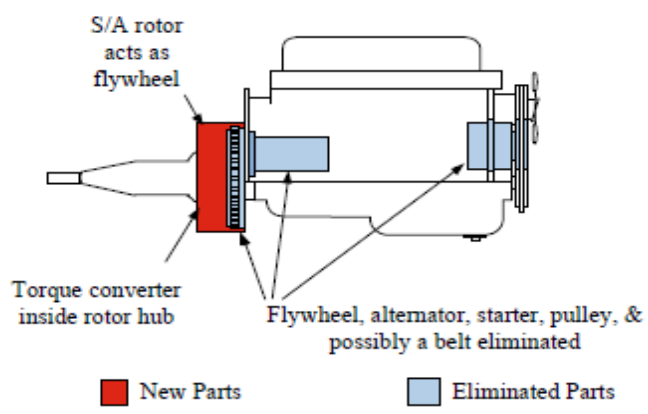

Gambar. 1 Konfigurasi Integrated Starter / alternator (ISA)

Aplikasi yang telah memotivasi pekerjaan ini adalah sebuah direct drive terpadu pemula / alternator (ISA) untuk otomotif kendaraan. Banyak perkembangan electrically- baru aksesoris bertenaga dikombinasikan dengan kepentingan luas dengan konsep hybrid ringan menggunakan mesin listrik untuk kecepatan rendah akselerasi telah menarik perhatian yang signifikan untuk sistem ISA Seperti diilustrasikan dalam Gambar. 1

Spesifikasi kinerja yang dikembangkan melalui konsultasi dengan beberapa produsen otomotif panggilan untuk ISA untuk memasok $150 \mathrm{~nm}$ memulai torsi pada kecepatan rendah. Selain itu, ISA harus memberikan daya $42 \mathrm{~V}$ ke aksesoris otomotif selama kisaran 10 : 1 kecepatan membentang dari $4 \mathrm{KW}$ di $600 \mathrm{rpm}$ untuk $6 \mathrm{KW}$ di 6000rpm. Ini adalah persyaratan yang terakhir yang seleksi termotivasi dari mesin PHT untuk lebih lanjut pembangunan sebagai kandidat yang menarik untuk aplikasi ini.

Gambar 2. Menunjukkan mesin stator dan rotor, menggambarkan penggunaan dari dua rongga magnet per tiang dengan menjenuhkan jembatan magnetik yang menghubungkan tiang besi potongan menjadi laminasi rotor.

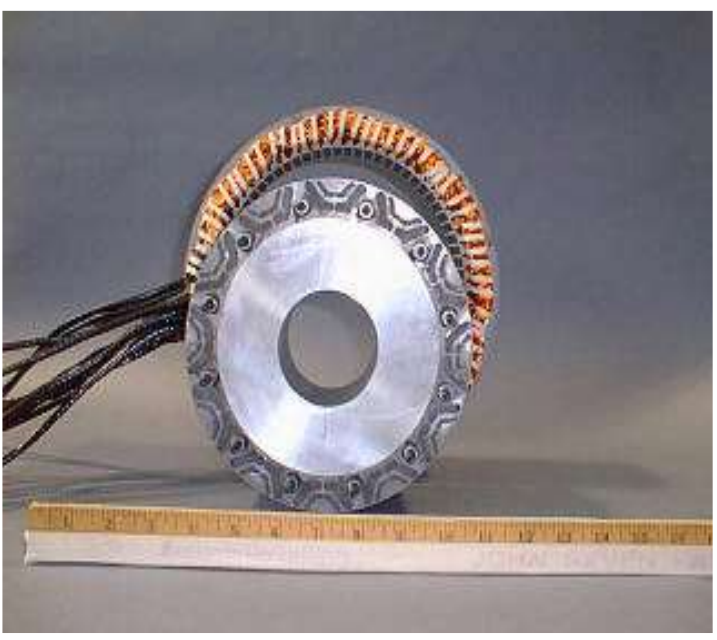

Gambar. 2 Rotor dan stator tipe proto $6 \mathrm{~kW}$ IPM mesin untuk aplikasi ISA.

Prinsip-prinsip untuk mencapai daya konstan lebar operasi menggunakan PHT mesin sinkron telah didirikan pada literatur teknis. Mesin persamaan yang mengatur operasi dinamis dari IPM mesin di rotor kerangka acuan dq dirangkum di bawah ini. Perhatikan bahwa sumbu d sejajar dengan rotor fluks magnet permanen [1].

$$
\begin{aligned}
& v_{d}=r_{s} i_{d}+p \lambda_{d s}-\omega_{r} \lambda_{q s} \\
& v_{q}=r_{s} i_{q}+p \lambda_{q s}+\omega_{r} \lambda_{d s} \\
& \lambda_{d s}=L_{d s} i_{d}+\phi_{p m} \\
& \lambda_{q s}=L_{q s} i_{q}
\end{aligned}
$$

\section{Dimana :}

$i d$ dan $i q=$ arus stator pada sumbu d dan q [A] $\mathrm{vd}$ dan $\mathrm{vq}=$ tegangan stator pada sumbu $\mathrm{d}$ dan $\mathrm{q}$ [V]

$\kappa_{d s}$ dan $\kappa_{q s}=$ hubungan fluks stator pada sumbu d dan $\mathrm{q}[\mathrm{Wb}]$

$\mathrm{L}_{d s}$ dan $\mathrm{L}_{q s}=$ induktansi stator pada sumbu d dan $\mathrm{q}$ [H]

(Perhatikan bahwa LQs> Lds di mesin IPM)

$\phi_{\mathrm{pm}}=$ hubungan sumbu d dengan fluks magnet permanen $[\mathrm{Wb}]$

$\mathrm{w}_{\mathrm{r}}=$ frekuensi rotasi rotor $[\mathrm{elec} . \mathrm{rad} / \mathrm{s}]$

kontrol kinerja kecepan motor dan statistik dan membuat algoritma inheren adaptif terhadap perubahan inverter tegangan bus. Sebuah $6 \mathrm{~kW} 42 \mathrm{~V}$ otomotif terpadu Starter / alternator (ISA) menggunakan direct-drive mesin IPM merupakan penerapan target untuk pengembangannya. Hasil simulasi menunjukkan bahwa algoritma baru ini mampu memberikan regulasi bus statis dan dinamis yang sangat baik Karakteristik selama 10: 1 mesin rentang kecepatan operasi. Tes yang saat ini 
sedang berlangsung untuk mengkonfirmasi kinerja tersebutprediksi menggunakan prototipe IPM sistem Starter / alternator [1].

\subsection{Metode control EV / HEV bidirectional}

Metode EV/HEV Bidirectional ini dapat mengendalikan arus pengisian baterai konstan[2].

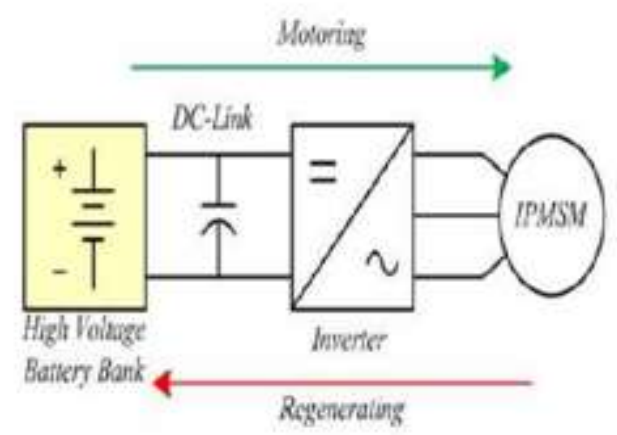

(a)

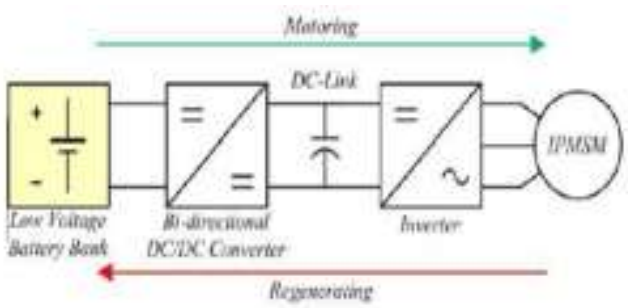

(b)

Gambar. 3 Diagram konseptual sistem EV traksi (a) Satu Tahap inverter sistem EV traksi (b) Dua tahap (Converter Bi-directional dan inverter) EV traksi sistem

Seperti pada Gambar. 3 (a), jenis yang terdiri dari hanya baterai dan inverter memiliki manfaat untuk dapat meningkatkan efisiensi dengan meminimalkan perangkat. Namun, Baterai tegangan tinggi umumnya disusun oleh serangkaian sel baterai terhubung dengan output tegangan rendah. Semakin banyak seri sel yang terhubung digunakan, semakin banyak masalah yang dibuat seperti ketidakseimbangan tegangan setiap sel atau penurunan harapan hidup baterai. Selain itu, sistem Gambar. 3 (a) memiliki kekurangan karena tegangan output

bervariasi dengan arus keluaran. Hal ini disebabkan oleh internal resistor baterai. Ini variasi tegangan output membatasi kekuasaan dan kontrol kinerja keluaran inverter.

Untuk mengatasi masalah ini, dua-tahap EV traksi sistem Gambar. 3 (b) yang diusulkan dalam [2]. Sistem ini tambahan menempel konverter DC / DC mengontrol aliran daya dua arah antara inverter dan baterai. Sistem ini lebih kompleks daripada sistem Gambar. 3 (a). Namun, tegangan mendorong disesuaikan dengan traksi Sistem EV menggunakan tegangan baterai relatif kecil dan berbagai motor traksi sesuai dengan kapasitas daya EV. Selain itu, Sistem ini mempertahankan tegangan DC-link inverter dalam batas toleransi apa pun saat inverter bekerja.

Banyak topologi yang dikembangkan untuk sistem Gambar.3 (b). Di antara mereka, Jenis konverter DC / DC full-bridge, dan converter menggunakan transformator.

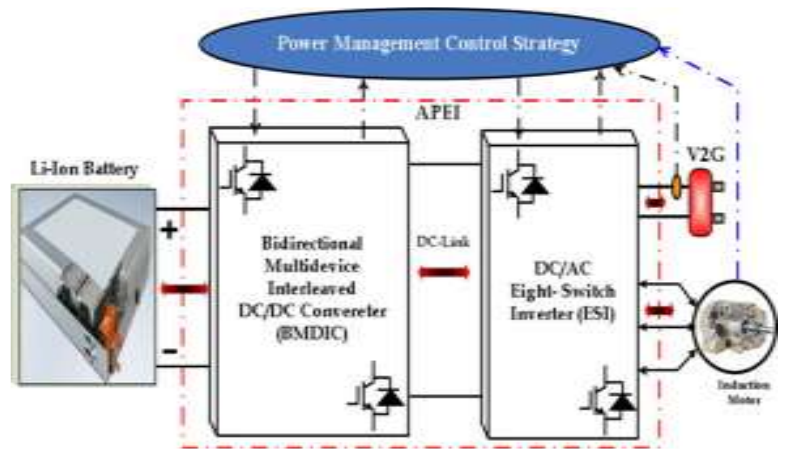

Gambar 4. Blok diagram dari BEV powertrain

Dalam prakteknya, integrasi $\mathrm{dc} / \mathrm{dc}$ converter dan dc / ac inverter adalah pilihan yang menarik untuk membentuk kendaraan listrik hibrida (HEV) powertrain. Oleh karena itu, konverter dan integrasi mereka bersama-sama memainkan peran penting untuk keberhasilan pengembangan kinerja yang efisien dan tinggi BEVs dan PHEVs [8]. pengisi daya baterai adalah kunci lain komponen yang dibutuhkan untuk munculnya dan penerimaan BEVs dan PHEVs. Terutama, on-board pengisi baterai harus kecil dan ringan. Oleh karena itu, beberapa ac / dc dua arah converter topologi dapat dimanfaatkan sebagai on-board charger baterai.

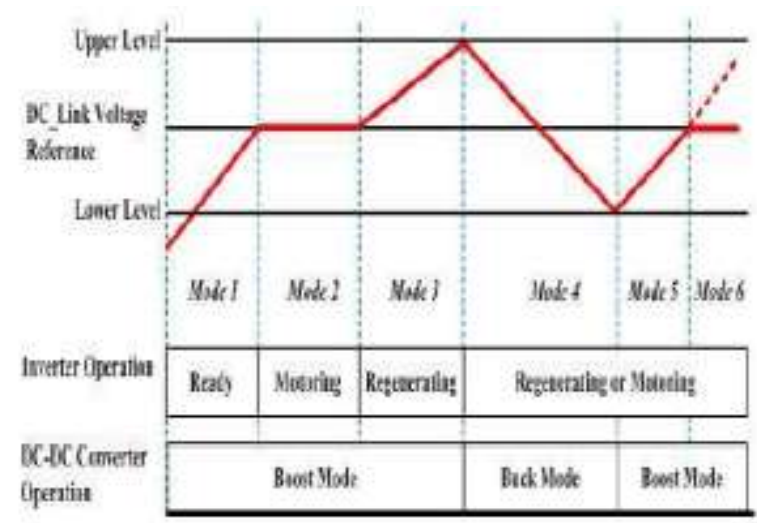


Gambar. 5. DC-Link rentang variasi tegangan sesuai dengan Mode operasi inverter dan converter

Gambar. 5 menunjukkan kisaran variasi tegangan DC-link menurut inverter dan converter operasi dengan metode kontrol. Seperti telah disebutkan, mode operasi dari konverter DC / DC diubah oleh DC-link tegangan. Setiap variasi tegangan DC-link dapat dibagi menjadi enam mode. Mode 1, 2, 3, 5, 6 adalah dorongan operasi, dan Mode 4 adalah operasi buck DC-DC converter.Mode 1 sedang mempersiapkan operasi untuk cocok DClink tegangan inverter. Jika tegangan DC-link mencapai referensi, Mode 1 adalah akhir dan Mode 2 adalah start. Detail penjelasan mode operasi ini dijelaskan pada Bagian Percobaan dengan operasi inverter [2].

\section{3 metode control full cel}

Metode ini diharapkan menjadi sumber daya yang menarik untuk otomotif aplikasi karena mereka bersih, efisiensi, dan kehandalan yang tinggi. FCS adalah elektrokimia perangkat yang langsung mengubah energi kimia bahan bakar menjadi listrik. Ada berbagai jenis FCS ditandai dengan elektrolit mereka. Salah satu yang paling menjanjikan dimanfaatkan untuk stasioner atau aplikasi diangkut adalah membran polimer elektrolit FC (PEMFC) karena relatif kecil ukuran dan desain yang sederhana. Ini memiliki kepadatan daya terlalu tinggi dengan suhu operasi yang lebih rendah ketika dibandingkan dengan jenis lain dari sistem FC [6].

Meskipun sistem FC menunjukkan kemampuan daya yang baik selama operasi steadystate, dinamis respon FCS selama tuntutan puncak kekuasaan sementara dan sesaat relatif lambat. Oleh karena itu, untuk meningkatkan kinerja sistem FC selama tuntutan puncak kekuasaan sementara dan seketika dalam aplikasi kendaraan listrik, sistem FC selalu dikaitkan dengan sistem penyimpanan energi (ESS) (mis, baterai dan / atau supercapacitors). ESS dapat digunakan untuk memulihkan energi melalui regeneratif pengereman. Untuk aplikasi ini, kekuatan-tinggi dc / dc converter merupakan elemen kunci bahwa antarmuka FC atau ESS dengan bus dc di powertrain dari EVS. Oleh karena itu, desain daya tinggi dc / dc konverter dan pengontrol mereka memainkan peran penting untuk mengontrol kekuatan regulasi terutama untuk FC [3] [6].

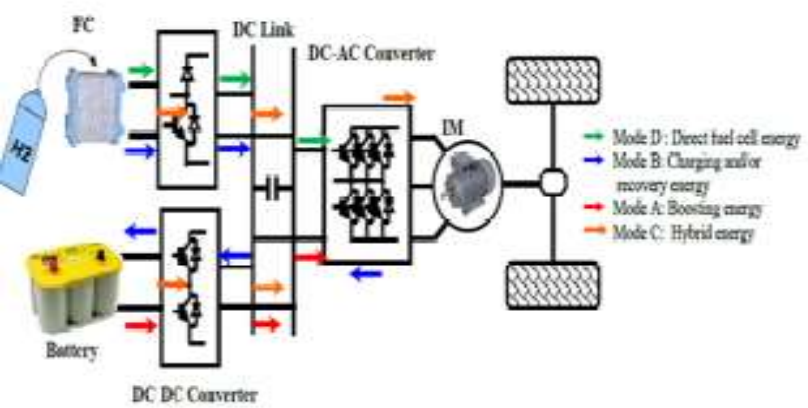

Gambar. 6 Block diagram dari FCEV

FC Electric Vehicle (FCEV), seperti ditunjukkan pada Gambar. 6, menggunakan sebuah FC sebagai sumber daya utama dan ESS (Baterai) sebagai sumber daya tambahan untuk membantu penggerak kendaraan selama transien dan untuk memulihkan energi saat pengereman regeneratif. Dalam konfigurasi ini, FC terhubung ke dc bus melalui IBC, sedangkan ESS terhubung ke bus dc melalui dua arah dc / dc converter. Seperti yang telah disebutkan di banyak literatur, dc / dc converter adalah salah satu yang paling penting komponen dalam sistem FC bertenaga. Hal ini memungkinkan tingkat yang diinginkan dari tegangan dc yang akan diperoleh tanpa harus meningkatkan ukuran stack.

Gambar. 7 menunjukkan simulasi karakteristik debit kurva untuk asam timbal Yuasa Np18-12 baterai untuk berbagai arus discharge [6].

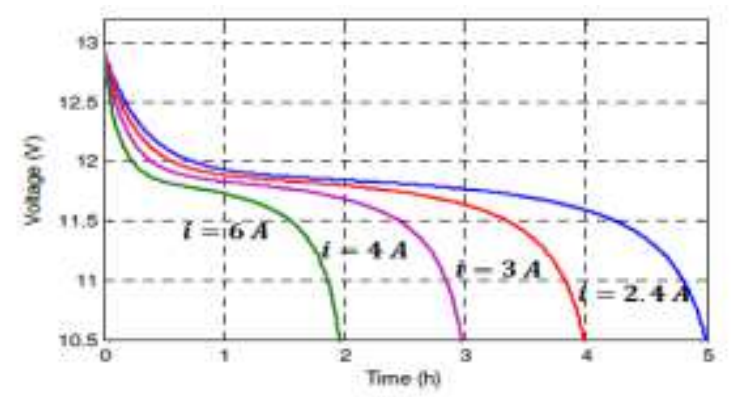

Gambar. 7 statistik pemakaian batterai

\subsection{Penambahan capasitor pada sistim mobil} listrik

Ultracapacitors penting di bidang penyimpanan energi di kendaraan listrik hybrid. Ultracapacitors dapat digunakan untuk memberikan ledakan singkat energi yang dibutuhkan oleh kendaraan listrik hibrida saat akselerasi. Ultracapacitors tidak perlu penggantian yang teratur seperti baterai karena mereka tidak terpengaruh selama pengisian berulang-ulang dalam dan pemakaian. Hal ini juga menyiratkan bahwa ultracapacitors lebih ramah lingkungan karena mereka tidak perlu sering dibuang. Ultracapacitors dapat terisi penuh dari debit keseluruhan dalam beberapa 
detik. Hal ini membuat mereka ideal untuk digunakan dalam sistem melanggar regeneratif. Ultracapacitors tidak rentan terhadap efek suhu seperti baterai dan dapat beroperasi pada temperatur serendah $40{ }^{\circ} \mathrm{C}$. Ultracapacitors tidak dapat menggantikan baterai sepenuhnya; namun mereka dapat digunakan untuk melengkapi satu sama lain. Dalam kendaraan listrik hibrida, ultracapacitor dapat digunakan selama operasi kendaraan Lihat gambar 8 ultracapacitor dapat dihubungkan dalam hubungan shunt dengan DC I DC converter dari ESS dari PHEV tersebut.

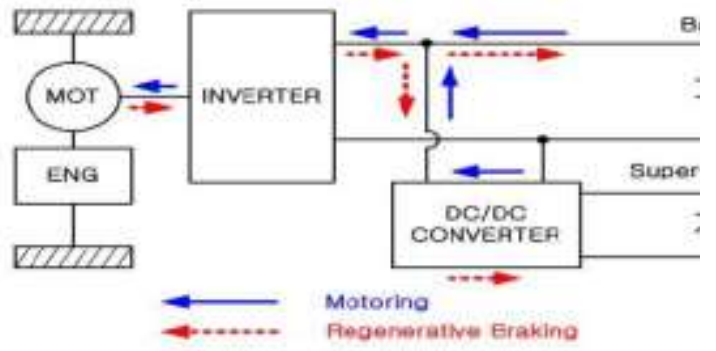

Gambar. 8 Usulan PHEV Energy Storage System dengan Super-kapasitor

\section{Kesimpulan}

Berdasarkan pembahasan dari beberapa jurnal metode metode kontrol pada mobil listrik pada jurnal ini dapat disimpulkan

$>$ Ketika melemahnya fluks algoritma untuk IPM mesin alternator sinkron cocok untuk menarik mesin untuk menghasilkan tenaga yang konstan dengan rentang kecepatan (10: 1 atau lebih tinggi). Keuntungan dari algoritma ini termasuk kemampuannya secara otomatis beradaptasi dengan perubahan bus tegangan dengan menggunakan indeks modulasi PWM untuk mengenali ambang kejenuhan regulator.

> Metode kontrol bidirectional DC / DC converter untuk aplikasi EV / HEV dijelaskan dalam makalah ini. Untuk mengontrol pengisian baterai saat konstan, masing-masing mode operasi tiga fase interleaved dua arah DC / DC converter yang dipilih sesuai dengan variasi tegangan DC-link. Berbeda dengan metode konvensional, pengisian baterai saat ini tidak terpengaruh oleh kecepatan motor dengan metode kontrol yang diusulkan.

$>$ analisis sistem tenaga hibrid FC-IBC / baterai dan desain untuk aplikasi kendaraan listrik. membahas Manajemen mode daya yang berbeda. Mode operasi efisien untuk dioperasikan sistem tenaga baterai FC, FC-IBC converter Sistem ini dirancang dan dimodelkan, kontrol manajemen daya aktif saat sistem dirancang untuk mengakomodasi Status FC, SOC baterai, dan permintaan kendaraan listrik. Hasil Dinamis dan SteadyState disediakan untuk membuktikan kelayakan desain sistem ini.

\section{Daftar Pustaka}

[1] Jackson Way, Thomas M. Jahn. A New Control Technique for Achieving Wide Constant Power Speed Operation with an Interior PM Alternator Machine. University of Wisconsin-Madison.

[2] Jung-Hyo Lee, Doo-Yong Jung, Taek-Kie Lee, Young-Ryul Kim and Chung-Yuen Won. Regenerative Current Control Method of Bidirectional DC/DC Converter for EV/HEV Application. Jeet vol. 8, no 1 : 97

[3] Md Shamiur Rahman, Asif Hassan, Nasif Mahmud, Ahmed Tashfin Iftekhar, Mohammad Delwar Hossain Mazumder. Power Management and Control of Grid Connected Photovoltaic System with Plug in Hybrid Vehicle Load. IJAREEIE vol. 3 ISSUE 1, Januari 2014

[4] Bo Long, Shin Teak Lim, Zhi Feng Bai, Ji Hyoung Ryu and Kil To Chong. Energy Management and Control of Electric Vehicles, Using Hybrid Power Source in Regenerative Braking Operation. ISSN 1996-1073 Energies 2014, 7, 4300-4315; doi:10.3390/en7074300.

[5] Shuangxia Niu, K.T. Chau, Senior Member, IEEE, and J.Z. Jiang. A Permanent-magnet Double-stator Integratedstarter- generator for Hybrid Electric Vehicles. IEEE Vehicle Power and Propulsion Conference (VPPC), September 3-5, 2008, Harbin, China

[6] A. Benrabeh, F. Khoucha, O. Herizi, M.E.H. Benbouzid and A. Kheloui Ecole Militaire Polytechnique. FC/Battery Power Management for Electric Vehicle Based Interleaved dcdc Boost Converter Topology. Author manuscript, published in "EPE ECCE Europe 2013, Lille : France (2013)"

[7] Wei Xu, Jianguo Zhu, Yongchang Zhang, Yi Wang, Guangyong Sun. Characterization of Advanced Drive System for Hybrid Electric Vehicles

[8] Omar Hegazy, Member, IEEE, Ricardo Barrero, Joeri Van Mierlo, Member, IEEE, Philippe Lataire,Noshin Omar, and Thierry Coosemans. An Advanced Power Electronics Interface for ElectricVehicles Applications. IEEE TRANSACTIONS ON [1]POWER ELECTRONICS, VOL. 28, NO. 12, DECEMBER 2013 